\title{
Pemantauan Kinerja Sistem Manajemen Kesehatan Keselamatan Kerja Lindung Lingkungan berdasarkan ISO 45001, 14001 dan 9001 di KSO CESL
}

\section{Monitoring Performance Occupational Health Safety and Environmental Protection Based on ISO 45001, 14001 dan 9001 at KSO CESL}

Sri Suhardono ${ }^{\mathrm{a}}$, Bambang Pramudya Noorachmat ${ }^{\mathrm{b}}$, Andes Ismayana $^{\mathrm{c}}$

aprogram Studi Ilmu Pengelolaan Sumberdaya Alam dan Lingkungan, Sekolah Pascasarjana, Institut Pertanian Bogor, Kampus Darmaga, Bogor 16680

beparmeten Teknik Mesin dan Biosistem, Fakultas Teknologi Pertanian, Institut Pertanian Bogor, Kampus IPB Darmaga, Bogor 16680

'Departemen Teknologi Industri Pertanian, Fakultas Teknologi Pertanian, Institut Pertanian Bogor, Kampus IPB Dramaga, Bogor 16680

\section{Article Info:}

Received: 10 - 10 - 2018

Accepted: 08 - 04 - 2019

\section{Keywords:}

Management system, power query, power pivot, occupational health safety environment.

Corresponding Author: Sri Suhardono

Program Studi Ilmu Pengelolaan

Sumberdaya Alam dan

Lingkungan, Sekolah

Pascasarjana;

Email:

sri.suhardono@hotmail.com

\begin{abstract}
Monitoring Performance of Occupational Health Safety and Environmental Protection Management System (OHSEMS) Based on ISO 45001, 14001 and 9001 is a methodological approach to managing interaction for implementation policies, processes, and regulations. Risk identification modeling used to ensure that activities can run properly in accordance with regulations and standards which are part of the performance management system measurement. Risk control modeling as a verification tool for OHSE events in drilling activities as much as 90, producing 325. Stakeholder regulations as many as 27 with total expectations 108 out of a total of 28 revisions with a total expectation of 225 in standard regulatory database modeling. OHSEMS improvement uses data on OHSE events from 2013 to June 2018. Drilling activities have 16 events with a number of standard regulations 14 and the number of suggestions for improvement 23, the number of recommended suggestion as many as 16. Production activities there are 25 occurrences of the number of standard regulations 16 with suggestions improvements 42 and recommendations for improvements was 25. In the OHSEMS improvement in drilling activities based on OHSE events is to socialize drilling work procedures. In production activities to reduce the occurrence of oil spills that can cause environmental impacts, make improvements to facilities as well as emergency response prevention training can be done to control events caused by human factors and production equipment.
\end{abstract}

How to cite (CSE Style $8^{\text {th }}$ Edition):

Suhardono S, Noorachmat BP, Ismayana A. 2019. Pemantauan kinerja sistem manajemen kesehatan keselamatan kerja lindung lingkungan berdasarkan ISO 45001, 14001 dan 9001 di KSO CESL. JPSL 9(3): 840-860. http://dx.doi.org/10.29244/jpsl.9.3.840860 .

\section{PENDAHULUAN}

Dewasa ini Sistim Manajemen Kesehatan Keselamatan Kerja Lindung Lingkungan (SMK3LL) merupakan bagian integral dari sistem manajemen perusahaan dalam menjalankan aktifitas atau kegiatan. SMK3LL adalah suatu sistem untuk mengendalikan bahaya yang dapat menimbulkan dampak kerugian dari sisi Kesehatan Keselamatan Kerja dan Lindung Lingkungan (K3LL). Menurut Haight (2013) tidak ada proses 
SMK3LL atau alat bantu yang dapat mengurangi atau menghilangkan kejadian secara langsung, usaha memastikan tempat kerja dapat mencegah kejadian K3LL secara berkelanjutan, membutuhkan penerapan optimum dari alat bantu atau proses untuk diimplementasi dan diatur dengan baik. Sistem manajemen lebih menyiratkan pendekatan metodologi, historis dan diuji dalam mengelola interaksi serta implementasi kebijakan, proses, regulasi terkait dengan aktifitas perusahaan.

International Standard Organization (ISO) menerbitkan ISO 45001 tentang keselamatan dan kesehatan kerja, memiliki struktur sistem manajemen yang sama dengan sistem manajemen lingkungan ISO 14001 dan mutu ISO 9001. Tujuan penyamaan struktur adalah untuk mempermudah penerapan ke dalam manajemen sebuah organisasi atau perusahaan. Standar ISO tidak menetapkan aturan yang harus dipatuhi tapi cenderung kepada acuan atau panduan penerapan sistem manajemen sehingga mudah untuk diterapkan serta dinilai dari sisi kinerja dalam rangka perbaikan berkelanjutan.

Penerapan SMK3LL melalui kerangka Plan-Do-Check-Act (PDCA) merupakan pengulangan suatu rangkaian kegiatan dalam upaya perbaikan secara berkelanjutan dan merupakan langkah proses yang sederhana serta dikembangkan secara luas untuk diterapkan pada suatu sistem manajemen. Kajian kinerja manajemen terkait pelaksanaan SMK3LL merupakan hal yang mutlak dari suatu rangkaian proses kegiatan atau aktifitas sehingga perbaikan dapat dilakukan secara berkelanjutan ISO 45001 (2018).

Pemantauan kinerja suatu SMK3LL dilakukan secara terus menerus dan merupakan tantangan tersendiri bagi perusahaan untuk merencanakan, melaksanakan, memantau dan menilai serta melakukan suatu perbaikan dalam suatu siklus yang tidak terputus. Tujuan pemantauan kinerja adalah agar organisasi atau perusahaan dapat melakukan perbaikan terhadap langkah proses yang sudah dilakukan dan diharapkan perusahaan dapat menentukan sumber daya, dan program yang tepat sesuai dengan peraturan standar dari para pihak berkepentingan sesuai dengan kegiatan organisasi perusahaan.

Menurut Goetsch (2011) ada beberapa faktor yang berpengaruh terhadap kinerja K3LL yaitu faktor manusia, proses kerja dan mesin, teknologi baru yang kadang gagal memenuhi harapan. Pada era teknologi tinggi, keterlibatan manusia dalam proses kerja masih merupakan kunci untuk peningkatan produktivitas yang paling signifikan dan bertahan lama. Jika mesin atau sistem tidak nyaman, terlalu rumit, atau berbahaya untuk digunakan, maka pekerja tidak akan dapat memperoleh manfaat penuhnya. Pengendalian operasional perusahaan berdasarkan ruang lingkup organisasi dan perencanaan, harus diperiksa secara rutin untuk mendapatkan data penurunan kinerja sistem.

Menutut Karla et al. (2015) penerapan sistem manajemen secara terintegrasi dengan menggabungkan lebih dari satu standar, memiliki banyak keuntungan di dalam proses perbaikan manajemen yang dilakukan secara rutin, dan juga memiliki sedikit keuntungan dari sisi finansial.

Purwanto et al. (2014) menyatakan bahwa dengan meningkatnya kinerja penerapan proses K3LL akan menaikan keunggulan kompetitif akan tetapi tidak mempengaruhi kinerja finansial. Peningkatan kinerja finansial merupakan dampak dari keunggulan kompetitif. Dalam hal ini dapat dipahami karena dalam pengadaan barang dan jasa di Industri migas, mencantumkan syarat SMK3LL untuk menentukan lolos atau tidaknya suatu perusahaan dalam proses tender.

Industri minyak dan gas bumi (migas) merupakan sektor usaha yang memiliki banyak acuan dalam penerapan SMK3LL, hal ini dilatarbelakangi oleh sifat aktifitas yang memiliki tingkat risiko tinggi. Data kecelakan kerja yang tercatat oleh Direktorat Jendral Minyak dan Gas Bumi, angka kecelakaan dalam tahun 2016, tercatat 188 kecelakaan, 2015 tercatat 306 kecelakaan. Tahun 2016 tercatat 141 kecelakaan di sektor operasi hulu dan 47 kecelakaan di sektor operasi hilir (TIPKM 2017)

KSO Cooper Energy Sukananti Ltd, (KSO CESL) merupakan salah satu perusahaan yang mengelola lapangan migas terbatas. Kerja Sama Operasi (KSO) memiliki tujuan membantu meningkatkan produksi nasional sebagai upaya meningkatkan ketahanan energi. Kegiatan pengembangan lapangan migas ini meliputi perawatan sumur produksi, pemboran sumur pengembangan, pembangunan stasiun pengumpul, pembuatan sumur injeksi, pemasangan pipa penyalur, dan pembangunan jalan akses dari sumur minyak ke stasiun pengumpul. KSO CESL menerapkan ISO 45001 untuk mengawal proses penerapan K3, integrasi dan 
penyesuaian sistem manajemen lama OHSAS 18001 dilakukan dengan mengubah atau merevisi beberapa klausul di SMK3LL milik perusahaan. Dokumen upaya pengelolaan pemantauan lingkungan dilakukan secara terintegrasi dengan sistem manajemen K3.

SMK3LL dalam penerapan harus ditata secara baik dari sisi perencanaan, pelaksanaan, pengerjaan dan pengawasan sesuai dengan permintaan atau ekspektasi dari para pihak berkepentingan. KSO CESL merupakan perusahaan yang terdaftar pada bursa saham sehingga setiap kejadian yang mengakibatkan penurunan performa dari sisi K3LL akan berdampak pada harga saham perusahaan. Kejadian penurunan kinerja dan kecelakaan kerja memerlukan penanganan yang cepat dan tepat sesuai dengan peraturan standar dari para pihak berkepentingan sesuai dengan ruang lingkup organisasi, menurut Budiarto et al. (2018)

KSO CESL telah memiliki prosedur identifikasi bahaya dan pengendalian risiko serta matrik risiko dengan tujuan memberikan panduan bagi pekerja dalam menilai risiko suatu pekerjaan. Basis data risiko dan peraturan di bidang K3LL masih belum terintegrasi. Pencatatan risiko pekerjaan masih dilakukan secara mandiri oleh pekerja di lapangan. Menurut ISO 45001 (2018) pengendalian risiko merupakan bagian perencanaan suatu organisasi dan dapat digunakan sebagai alat verifikasi kinerja sistem. Kejadian K3LL telah ditindaklanjuti dan data disimpan dalam server perusahaan. Klasifikasi kecelakaan kerja dan tata acara penyelidikan mengikuti Pertamina EP sebagai pemilik lapangan atau wilayah kerja KSO CESL.

\section{Lokasi dan Waktu Penelitian}

Tujuan dari penelitian ini antara lain: (1) menyusun model sistem pengendalian risiko berbasis pemenuhan terhadap peraturan standar sebagai alat verifikasi kinerja SMK3LL, (2) menyusun model pelaporan kejadian atau kecelakaan K3LL, diharapkan saran perbaikan dapat dilakukan dengan cepat dan akurat, (3) mengkaji saran untuk perbaikan SMK3LL dengan menggunakan model pengendalian risiko melalui penggunaan data kejadian atau kecelakaan K3LL.

\section{METODE PENELITIAN}

\section{Lokasi dan Waktu}

Wilayah penelitian dilakukan di wilayah area penambangan milik PEP dan dikelola oleh KSO CESL dalam bentuk Kerja Sama Operasi. Lokasi penambangan terletak di darat Sumatra Selatan, lebih kurang $80 \mathrm{~km}$ sebelah Barat Daya Palembang, dan $20 \mathrm{~km}$ sebelah Tenggara Prabumulih dengan luas wilayah kerja 18,25 $\mathrm{km}^{2}$. Area wilayah tambang KSO CESL didalamnya terdapat beberapa tapak sumur hasil pengeboran, beberapa telah diproduksikan serta terintegrasi dengan fasilitas pengolahan. Untuk tujuan menjaga tekanan formasi terdapat sumur yang dialih fungsikan sebagai sumur injeksi, dengan memanfaatkan air terproduksi. Lingkup penelitian fokus pada dua aktifitas utama kegiatan hulu migas yaitu pengeboran dan produksi terkait dengan pemenuhan peraturan standar berdasarkan penilaian risiko. Penelitian dilaksanakan mulai Maret 2018 hingga Juni 2018, lokasi penelitian dapat dilihat pada Gambar 1.

\section{Bahan dan Alat}

Bahan yang digunakan dalam penelitian merupakan data primer dan sekunder. Alat yang digunakan dalam penelitian adalah komputer dan software untuk memproses datal, Excel 2016; Power query dan Power Pivot. Data sekunder dan data primer diperoleh di kantor Jakarta dan area wilayah kerja tambang KSO CESL. Data sekunder berupa data kejadian di kegiatan produksi dan pengeboran dari tahun 2013-2017. Data primer diperoleh dengan melakukan survey lapangan berbekal pada hasil olahan data sekunder berbentuk lembar analisa risiko. 


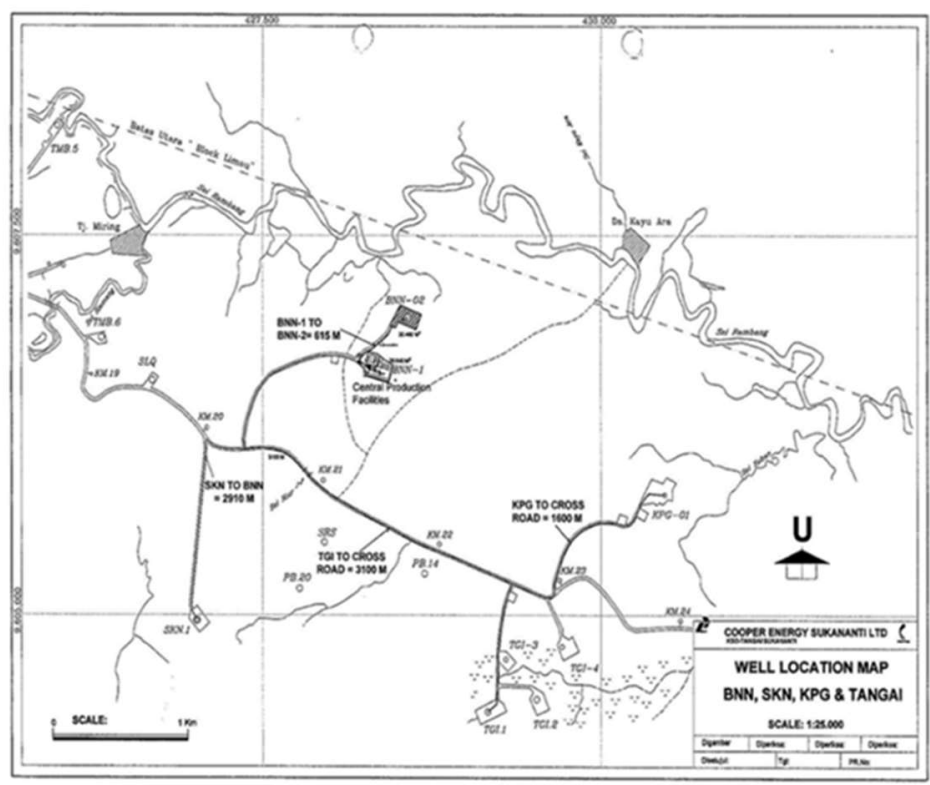

Gambar 1 Lokasi penelitian.

\section{Analisa Data}

\section{Pembuatan model basis data peraturan standar}

Daftar peraturan dan standar disesuaikan dengan bentuk usaha atau aktifitas organisasi. Sumber daftar peraturan dan standar dapat diperoleh dari lembar perundang-undangan yang dikeluarkan oleh para pihak berkepentingan, misalnya Kementrian Tenaga Kerja, Kementrian Lingkungan Hidup dan Kehutanan serta pihak berekepentingan yang lain seperti Kementrian Energi Sumber Daya Mineral, dan Pertamina EP sebagai perusahaan induk dari KSO CESL.

Para pihak berkepentingan dalam ISO masuk pada klausul 4 ruang lingkup organisasi. Pengertian ruang lingkup organisasi digunakan untuk menentukan batasan dalam pnyusunan dokumen SMK3LL. Eksternal internal isu harus dikelola dan dipantau untuk menjamin mutu organisasi dalam pemenuhan ekspektasi atau harapan dari paihak berkepentingan, isu bisa bersifat positif atau negatif terhadap perusahaan. Pemenuhan peraturan dan standar pihak berkepentingan bertujuan menghindari kejadian atau kecelakaan yang merugikan dan memiliki dapak hukum atau menurunnya citra organisasi. Pengertian tentang isu ekternal internal dapat dibaca pada Annex A (ISO 45001 2018), serta standar lainnya terkait lingkungan dan penjaminan mutu. Lembar kerja lingkup organisasi terdiri dua bagian utama terkait dengan klausul 4.1 dan 4.2 yaitu internal eksternal isu dan ekspektasi dari para pihak berkepentingan. Klausul 4.3, 4.4 tentang kajian aktifitas organisasi terhadap pemenuhan ekspektasi dan ketersedian dokumen K3LL. Pola alir data untuk lingkup organisasi atau klausul 4 ISO dapat dilihat pada Gambar 2

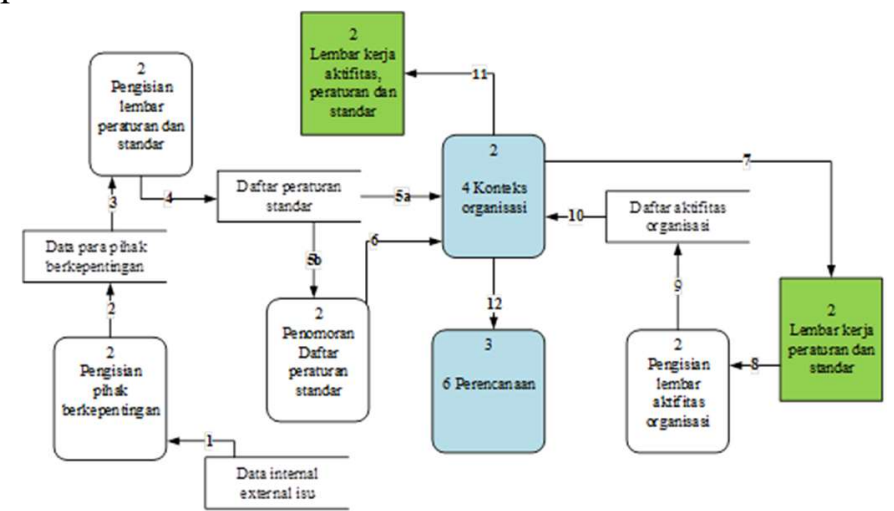

Gambar 2 Diagram alir data lingkup organisasi. 
Pola alir data dirangkum dalam satu lembar kerja untuk klausul 4 ruang lingkup organisasi, memiliki tiga persamaan query utama sesuai dengan klausul ISO yang dimodelkan, persamaan ini dapat dilihat pada Tabel 1, untuk memproses form isian klausul 4.1, 4.2, 4.3 sehingga dapat menghasilkan lembar kerja pengendalian data base peraturan standar sesuai dengan aktifitas organisasi.

Tabel 1. Pola alir data ruang lingkup organisasi

\begin{tabular}{ll}
\hline Persamaan query lingkup organisasi & Nomor aliran data \\
\hline 4 1 Pemahaman ruang lingkup organisasi & $5 \mathrm{a}, 5 \mathrm{~b}, 6$ \\
\hline 4 2 Kajian peraturan standar dan pihak berkepentingan & 7 \\
\hline 4 3 Lingkup K3LL MS dan aktifitas organisasi & 11 \\
\hline
\end{tabular}

\section{Pembuatan model basis data peraturan standar kegiatan dan aktifitas}

Pengendalian risiko merupakan hal yang utama dalam SMK3LL. Kegiatan analisa risiko merupakan langkah yang dilakukan oleh KSO CESL setiap melakukan perencanaan kegiatan atau aktifitas. Daftar analisa risiko di kegiatan produksi dan pengeboran menjadi data untuk penyusunan lembar pengendalian risiko dan bahaya sebagai dasar evaluasi pelaksanaan, pemeriksaan dan perbaikan. Penilitian dibatasi pada proses verifikasi kejadian K3LL terhadap basis data pengendalian risiko untuk dapat melakukan perbaikan SMK3LL dengan harapan kejadian yang sama tidak terulang. Diagram alir data untuk pengendalian risiko dapat dilihat pada Gambar 3. Data hasil kajian klausul 4 ruang lingkup organisasi, sub klausul 4.3 digunakan sebagai dasar untuk membuat tampilan muka pengendalian risiko, perbedaan dengan tampilan muka klausul 4 mengenai pembahasan risiko aktifitas adalah pada tampilan muka klausul 6 pengendalian risiko terdapat jenis bahaya tiap aktifitas sampai dengan nama pekerjaan secara detail. yang digunakan untuk memverifikasi setiap temuan penurunan kinerja. Penelitian ini menggunakan data kejadian KSO CESL yang telah diselidiki dan telah diketahui akar masalahnya, tindak lanjut saran perbaikan telah dilakukan. Tindak lanjut yang dilakukan dalam rangka perbaikan sistem akan dicocokan dengan kumpulan saran pada basis data pengendalian risiko. Lembar kerja identifikasi bahaya dapat membantu menentukan peraturan standar, jenis aktifitas yang terkena dampak serta lingkup dokumen K3LL terkait dengan kejadian atau kecelakaan K3LL. Klausul 4 tentang lingkup organisasi dan klausul 6 perencanaan digunakan sebagai alat verifikasi penentuan saran perbaikan kinerja suatu sistem.

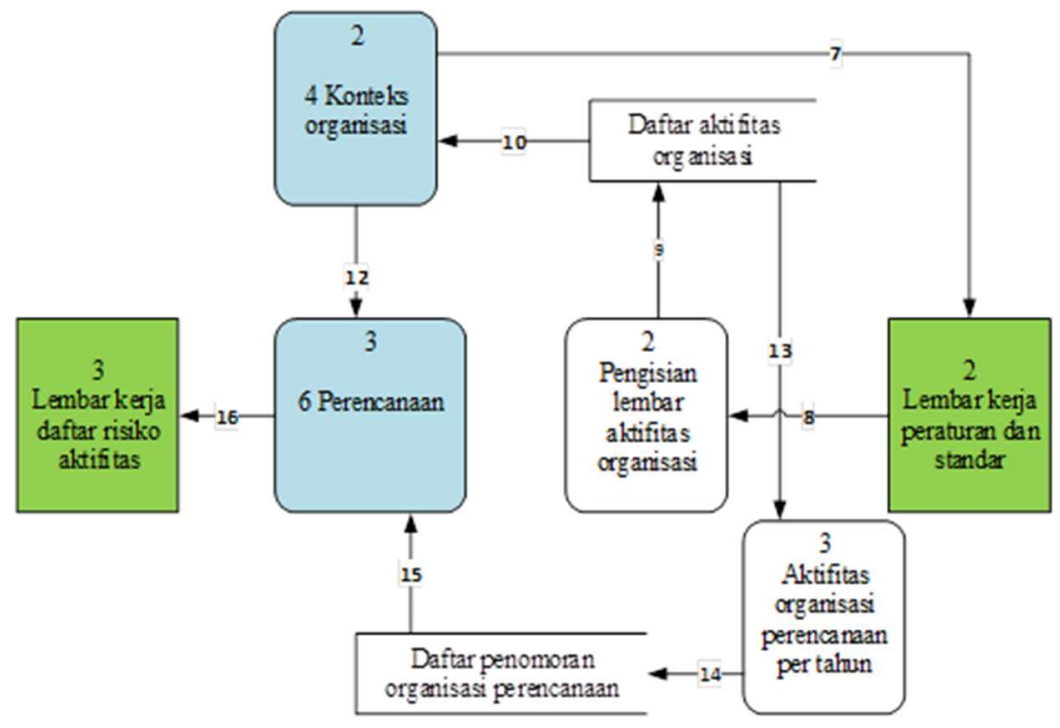

Gambar 3 Diagram alir data daftar pengendalian risiko.

Diagram alir data Gambar 3 dirangkum pada lembar kerja klausul 6 perencanaan yang terdapat pengendalian bahaya dan risiko 6.1. Pengendalian berisi saran tindakan mengatasi risiko dan peluang. Lembar 
kerja ini memiliki tiga persamaan query dari klausul 4 dengan dua persamaan yaitu nomor 4.2 status dari peraturan dan standar; menerangkan banyaknya peraturan yang telah masuk dalam basis data pengendalian risiko. sedangkan untuk tiga persamaan query dapat dilihat pada Tabel 2.

Tabel 2 Pola alir data daftar pengendalian risiko.

\begin{tabular}{cc}
\hline Persamaan query pengendalian risiko & Nomor aliran data \\
\hline 4 2 Status Peraturan Standar & 12 \\
\hline 4 Peraturan Standar dan ekspektasi & 12 \\
\hline 6 1 Penanganan risiko dan oportuniti & 15 \\
\hline
\end{tabular}

\section{Pembuatan model pelaporan kejadian K3LL}

Perbaikan SMK3LL berdasarkan data kejadian atau penurunan kinerja, dibagi menjadi dua bagian, otoritas memasukan data dan mengevaluasi daftar pengendalian risiko, pemenuhan terhadap peraturan standar serta jenis dokumen K3LL terkait dengan kejadian atau penurunan kinerja SMK3LL. Pembagian ini berdasarkan tingkat fungsi dan tanggung jawab pekerja yang menangani bagian K3LL. Operasional lapangan memerlukan akses untuk saran yang cepat dengan langkah kerja yang tidak rumit, analisa dan evaluasi klausul 4 ruang lingkup organisasi, klausul 6 perencanaan yang berisi daftar pengendalian risiko kegiatan dilakukan oleh kantor pusat. Operasional K3LL cukup menginformasikan apabila terdapat kejadian atau kecelakaan dalam aktifitas pekerjaan. Persamaan query untuk klausul 10 pada operasional lapangan terdapat satu lembar kerja dan kantor pusat dua lembar kerja yaitu saran perbaikan dan rekomendasi saran yang dihasilkan. Pola alir data untuk pelaporan lapangan dan kantor pusat dapat dilihat pada Gambar 4 dan 5 untuk persamaan query dapat dilihat pada tabel 3 dan 4 .

Lembar isian tersebut dilengkapi jenis bahaya, klasifikasi kejadian menurut Pertamina EP, serta rincian kegiatan atau aktifitas yang terdampak. Pemodelan ini menghasilkan data kejadian yang telah terklasifikasikan dan diketahui kejadian yang sering muncul dalam suatu kegiatan. Jenis bahaya dan kegiatan yang terdampak merupakan acuan untuk memverifikasi saran perbaikan.

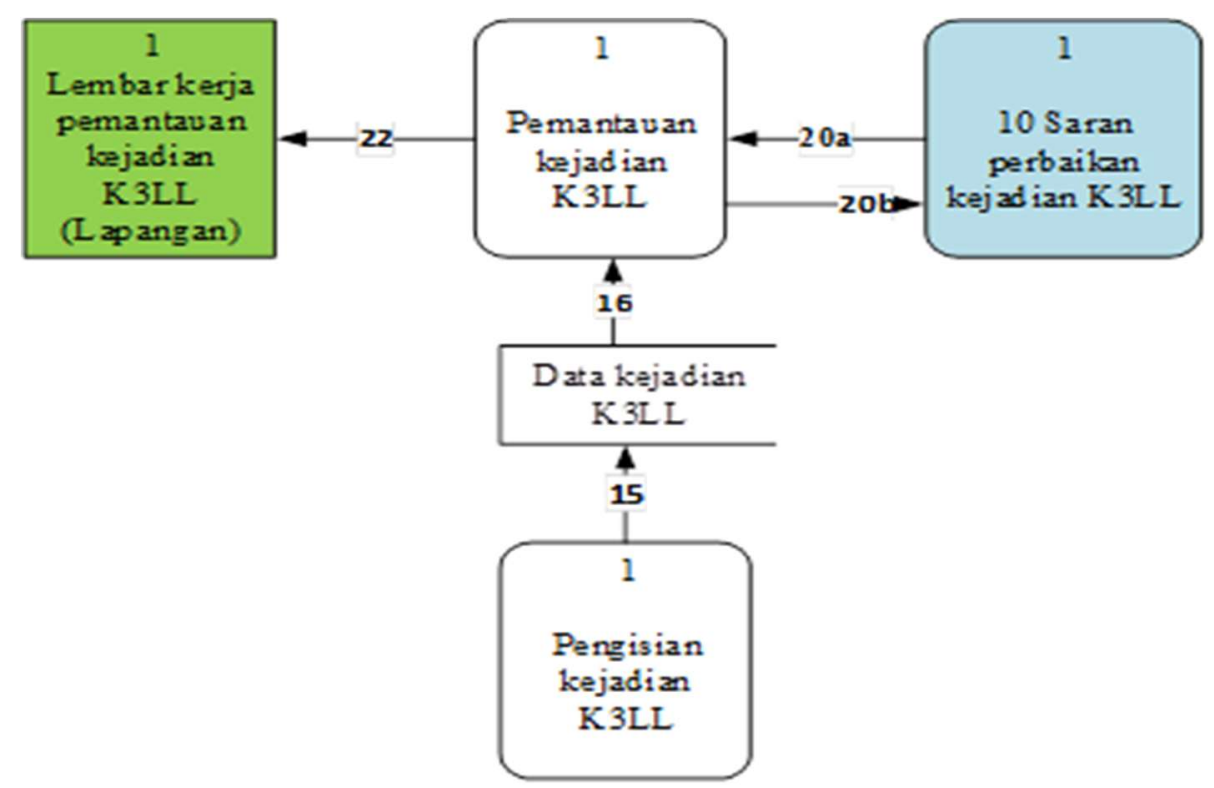

Gambar 4 Diagram alir data pelaporan kejadian operasional lapangan. 
Tabel 3 Pola alir data pelaporan operasional lapangan.

\begin{tabular}{ll}
\hline Persamaan query saran perbaikan & Nomor aliran data \\
\hline 01 Daftar kejadian & 15,16 \\
\hline 02 Saran perbaikan kantor pusat & 14 \\
\hline
\end{tabular}

Tabel 4 Pola alir data saran dan rekomendasi perbaikan.

\begin{tabular}{ll}
\hline Persamaan query saran perbaikan & Nomor aliran data \\
\hline 01 Daftar kejadian & 18 \\
\hline 02 Daftar pengendalian risiko dan oportuniti & 17 \\
\hline 03 Saran perbaikan & 21 \\
\hline 04 Rekomendasi perbaikan & 22 \\
\hline
\end{tabular}

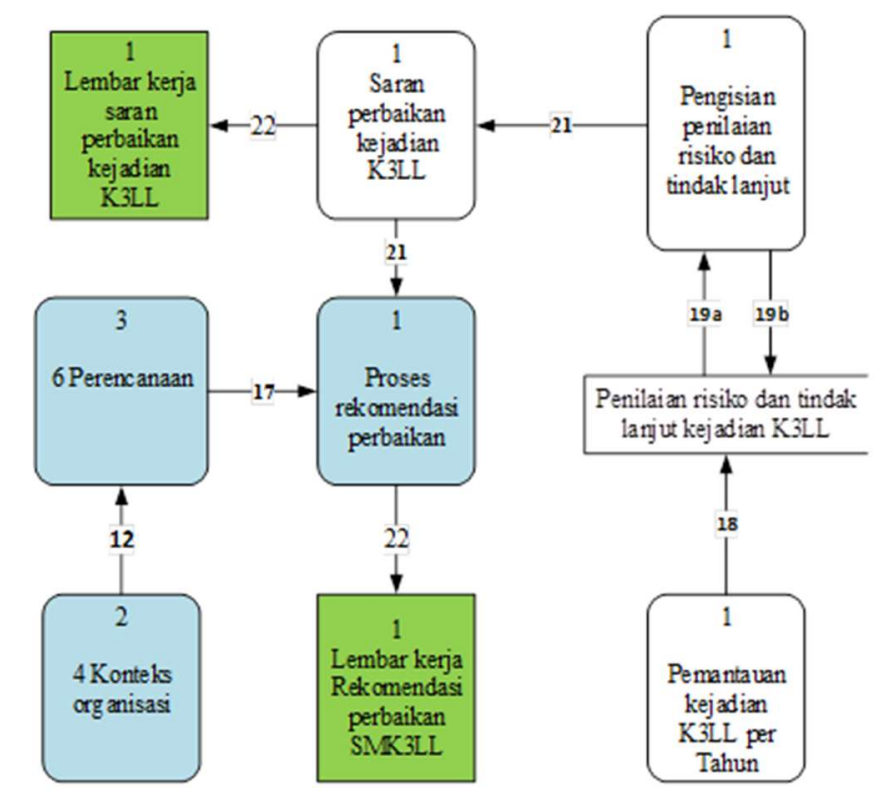

Gambar 5 Diagram alir data saran perbaikan kantor pusat.

\section{PEMBAHASAN}

\section{Model pemantauan peraturan dan standar}

Lembar kerja hasil pemodelan pemantauan peraturan dan standar termasuk pada klausul ruang lingkup organisasi dapat dilihat pada Gambar 6 . Untuk menggabungkan sumber data menggunakan power query yang mempunyai kemampuan untuk mengambil data dari sumber yang berbentuk folder atau file data dokumen (Puls dan Miguel 2016).

Lembar kerja pemantauan terdapat slicer yang membantu untuk menganalisa dan memilih peraturan dan standar sesuai risiko pada suatu aktifitas pekerjaan (Allington 2016). Slicer digunakan untuk menyaring basis data peraturan standar dibagi menjadi lima ketegori. Pertama adalah kategori jenis bahaya K3LL, kedua jenis konsekuensi peraturan standar, ketiga lingkup dokumen K3LL, keempat status peraturan standar dan ke lima adalah nomor serta nama peraturan standar. Ekternal atau internal isu, dicatat pihak berkepentingan yang mengeluarkan isu tersebut, kemudian dikaji oleh manajemen perusahaan dalam menentukan pengaruh terhadap jalannya organisasi, memperbarui data dapat dilakukan dengan melakukan langkah pada lembar kerja query yang dapat dilihat pada Gambar 7. Dilakukan proses "refresh" secara berurutan pada setiap persamaan query. 


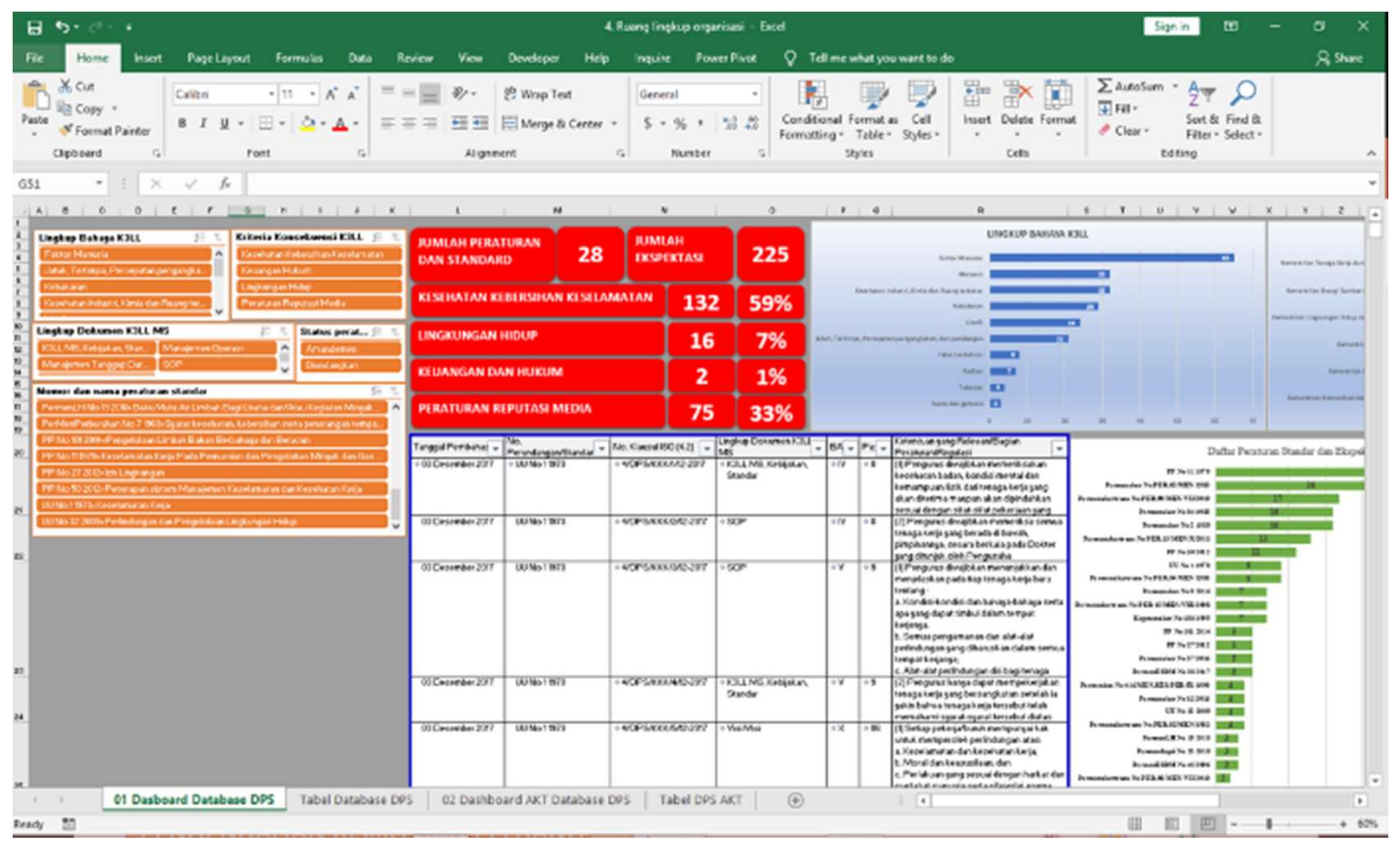

Gambar 6 Lembar pemantauan peraturan standar.

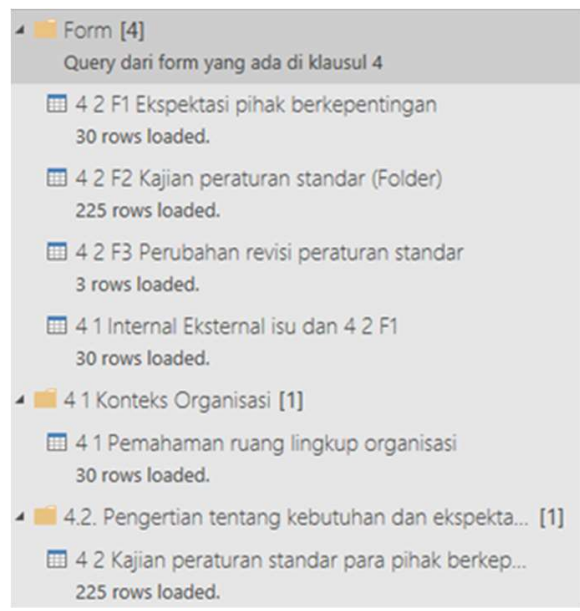

Gambar 7 Lembar kerja query basis data peraturan standar.

Hasil pemodelan basis data peraturan standar, dapat dibagi kriteria pihak berkepentingan terkait isu yang mungkin berpengaruh terhadap upaya organisasi untuk menjaga kinerja K3LL sesuai dengan tujuan dan mutu yang telah ditetapkan. Daftar pihak berkepentingan dapat dilihat pada Tabel 5.

Sebagian besar data peraturan berasal dari Kementrian Tenaga Kerja dan Transmigrasi yaitu 19 jenis peraturan dengan 159 ekspektasi atau harapan dari pihak berkepentingan tersebut. Menurut Haight (2013) kinerja K3LL memiliki fokus menjaga risiko dengan urutan manusia, peralatan atau aset dan lingkungan. Kejadian atau kecelakaan berdampak terhadap pekerja dan memiliki pengaruh besar terhadap citra atau reputasi perusahaan. Perusahaan membutuhkan pekerja yang terdidik dan mengerti jenis bahaya serta risiko pada aktifitas pekerjaanya. Kementrian Tenaga Kerja dan Transmigrasi banyak mengeluarkan peraturan yang mengatur bagaimana perusahaan menjaga keselematan para pekerja 
Tabel 5 Peraturan standar dari para pihak berkepentingan.

\begin{tabular}{cccc}
\hline Pihak berkepentingan & Jumlah peraturan & Jumlah ekspektasi & (\%) \\
\hline $\begin{array}{c}\text { Kementrian Tenaga Kerja dan } \\
\text { Transmigrasi }\end{array}$ & 19 & 159 & 68 \\
\hline $\begin{array}{c}\text { Kementrian Lingkungan Hidup } \\
\text { dan Kehutanan }\end{array}$ & 4 & 17 & 14 \\
\hline $\begin{array}{c}\text { Kementrian Energi Sumber } \\
\text { Daya Mineral }\end{array}$ & 3 & 42 & 11 \\
\hline Kementrian Dalam Negeri & 1 & 3 & 4 \\
\hline Kementrian Kesehatan & 1 & 4 & 4 \\
\hline Total & 28 & 225 & 100 \\
\hline
\end{tabular}

Total ekspektasi dari 28 peraturan standar berjumlah 225, jumlah ini berasal dari kajian setiap bab, pasal dikaitkan dengan jenis bahaya dan klasifikasi konsekuensi. Faktor manusia merupakan jenis paling banyak diatur sebanyak 65 ekpektasi dari peraturan dan standar, tingginya faktor manusia tersebut sesuai dengan data statistik penyebab kejadian atau kecelakaan K3LL, hampir 95\% akibat dari tindakan tidak aman pekerja (Hughes dan Ed 2009). Bahaya jatuh tertimpa, percepatan, pengangkatan dan pandangan menjadi nomor dua dari kegiatan pengeboran dan produksi. Lembar pencatatan peraturan standar akan berkembang sesuai dengan jenis aktifitas dan bahaya yang diatur

\section{Model pemantauan peraturan dan standar pada aktifitas organisasi}

Lembar kerja pemantauan peraturan standar pada aktifitas organisasi masih termasuk dalam klausul 4 ruang lingkup organisasi. Pemodelan ini mengambil data dari analisa risiko yang dilakukan oleh KSO CESL sebagai data sekunder dan proses analisa risiko yang dilakukan pada saat penelitian sebagai data primer. Hasil pemodelan adalah jumlah peraturan standar dan ekspektasi untuk setiap aktifitas. lembar kerja ini dilengkapi dengan jenis aktifitas sampai dengan nama pekerjaan, sehingga pada saat dilakukan penyaringan data base untuk proses analisa data dapat diketahui jumlah peraturan dan ekspektasinya, lembar kerja untuk mengetahui peraturan standar terkait dengan aktifitas perusahaan dapat dilihat pada Gambar 8.

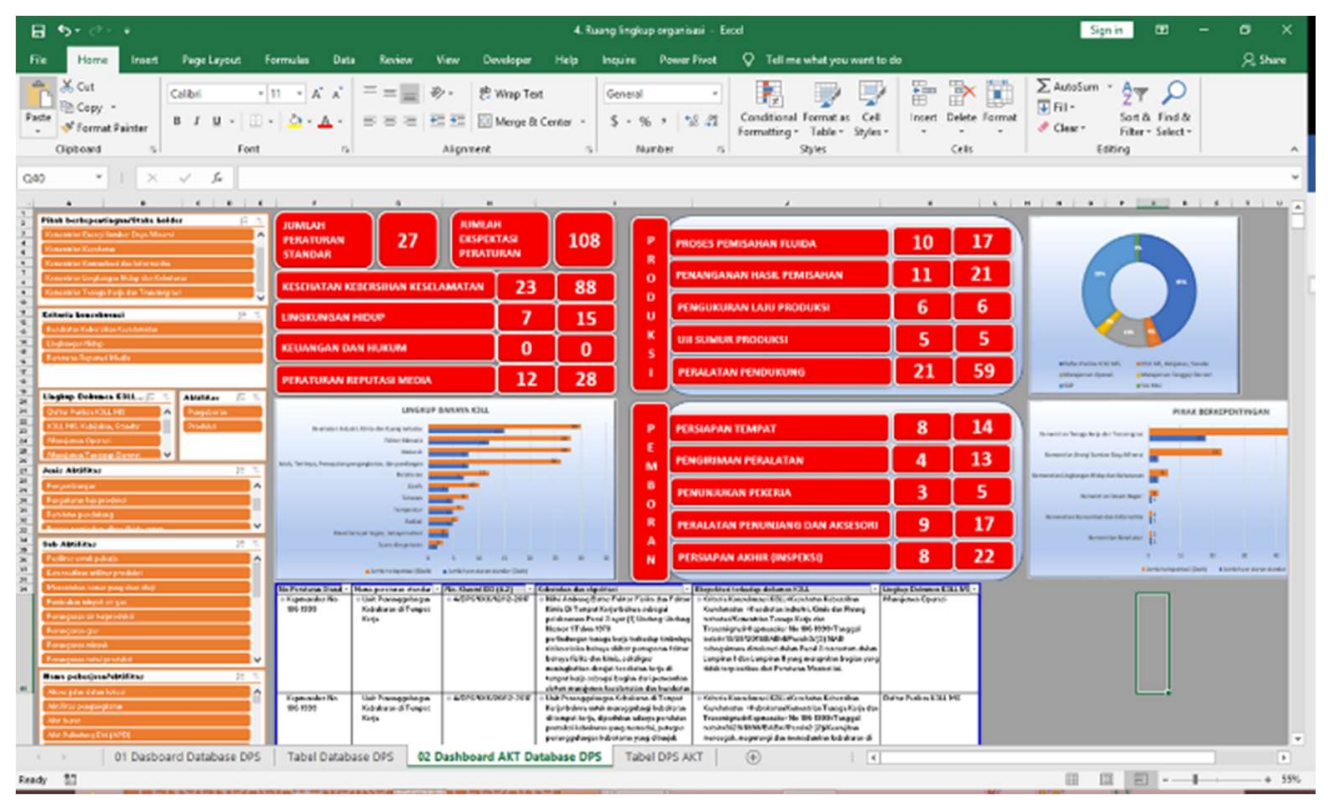

Gambar 7 Daftar peraturan standar dan aktifitas perusahaan. 
Penyaringan data base terdiri dari tujuh kategori; pertama yaitu pihak berkepentingan, kedua kriteria konsekuensi, ketiga lingkup dokumen K3LL, keempat aktifitas utama, kelima jenis aktifitas, keenam subaktifitas, ketujuh nama pekerjaan. Jumlah peraturan standar dan ekpektasi atau harapan dari pihak berkepentingan dapat dilihat pada Tabel 6 .

Tabel 6 Peraturan standar pada aktifitas organisasi.

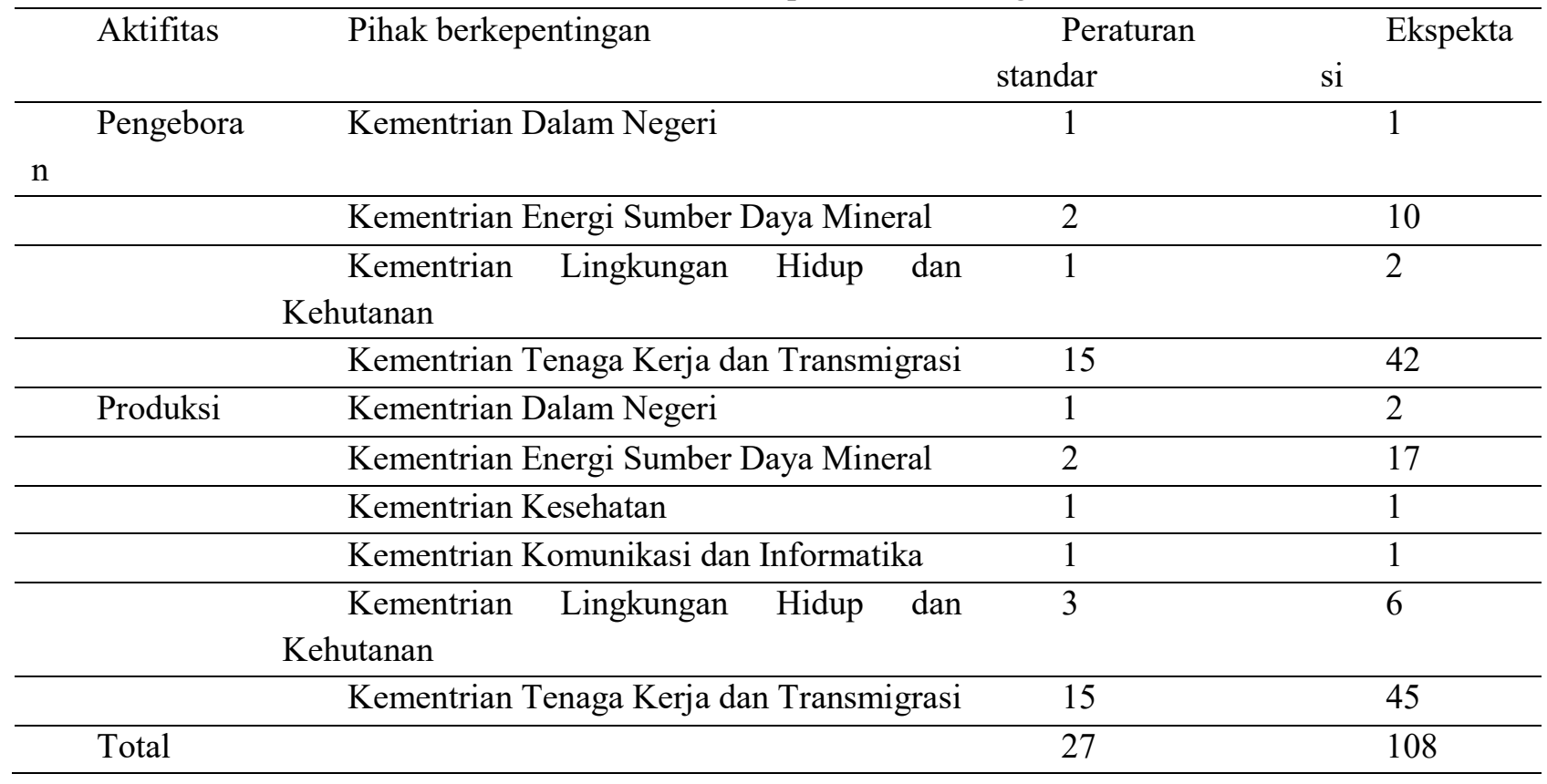

Jumlah peraturan total untuk aktifitas pengeboran dan produksi 27 , jumlah ekspektasi 108, dengan Kementrian Tenaga Kerja Transmigrasi memiliki jumlah aturan dan ekspektasi terbanyak yaitu 15 dan 42 pada kegiatan pengeboran serta 15 dan 45 pada kegiatan produksi. Untuk memonitor atau menjaga validitas dari lembar kerja ini, apabila terdapat aktifitas baru maka dilakukan proses "Refresh" secara berurutan pada lembar kerja query pada Gambar 8.

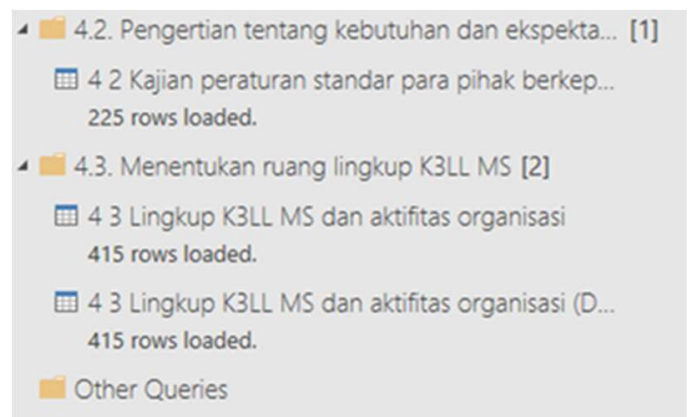

Gambar 8 Lembar kerja query daftar peraturan standar dan aktifitas.

Pada Gambar 9 dan 10, jenis bahaya pada aktifitas pengeboran dari data yang didapat faktor manusia menempati urutan pertama dengan total peraturan sebanyak 7 dan jumlah ekspektasi dari pihak berkepentingan 15 kemudian diikuti oleh faktor mekanik, jatuh tertimpa atau percepatan, kesehatan industri kimia ruang terbatas, kebakaran, listrik, tekanan, temperatur, dan penyakit atau bahaya biologi. Aktifitas produksi faktor kesehatan industri, kimia dan ruang terbatas menempati urutan pertama dengan jumlah peraturan 12 dan ekpektasi sebanyak 24, diikuti bahaya mekanik dengan 8 peraturan dan 18 ekspektasi. 


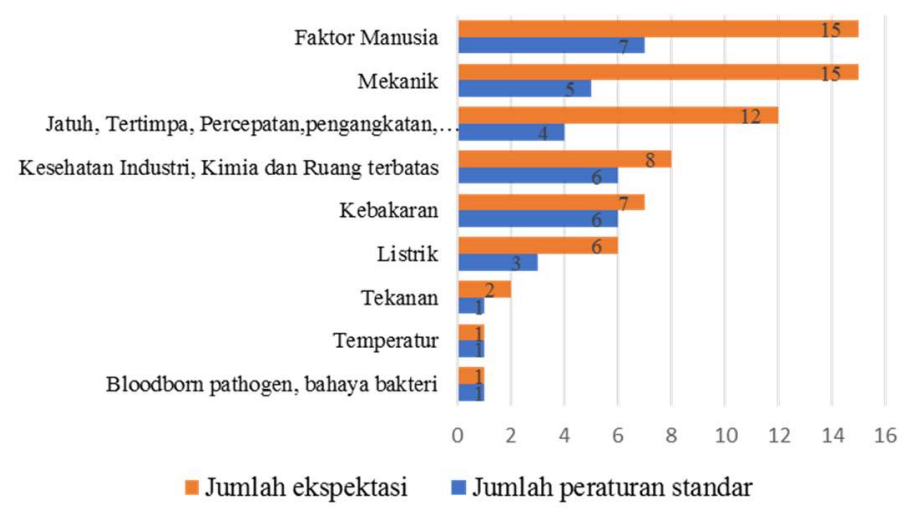

Gambar 9 Lingkup bahaya K3LL aktifitas pengeboran.

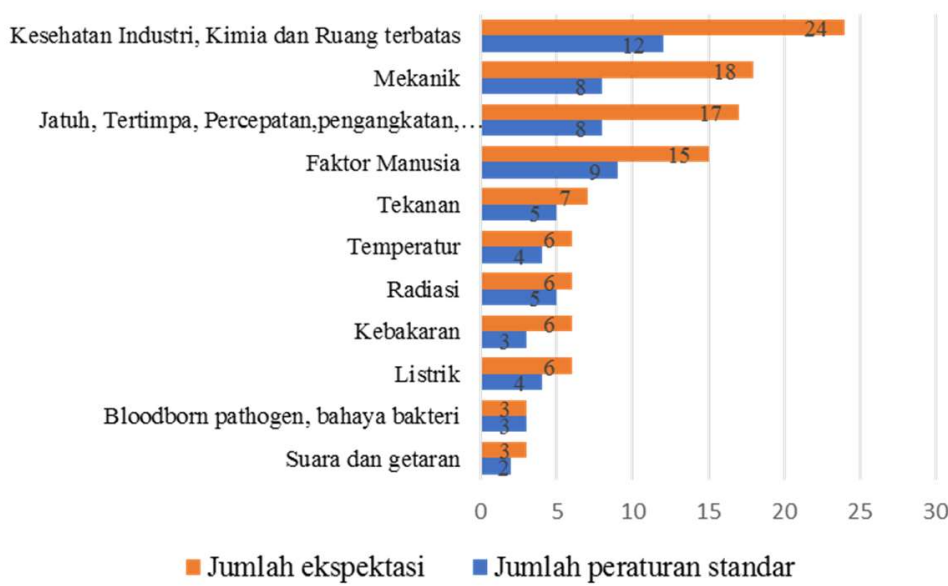

Gambar 10 Lingkup bahaya K3LL aktifitas produksi.

Jenis bahaya kegiatan pengeboran dan produksi beragam sesuai dengan penjabaran Goetsch (2011). Peraturan standar pada aktifitas pemboran menurut Rubiandini (2011) dan kegiatan produksi menurut Arnold dan Maurice (1989) berdasarkan ekspektasi atau harapan dari para pihak berkepentingan dapat dilihat pada Tabel 7 dan 8 .

Tabel 7 Peraturan dan ekspektasi pada aktifitas produksi.

\begin{tabular}{lll}
\hline Jenis aktifitas & Peraturan standar & Ekspektasi \\
\hline Penanganan hasil pemisahan & 11 & 21 \\
\hline Pengukuran laju produksi & 6 & 6 \\
\hline Peralatan pendukung & 21 & 59 \\
\hline Proses pemisahan aliran fluida sumur & 10 & 17 \\
\hline Testing sumur produksi & 5 & 5 \\
\hline Total & 23 & 72 \\
\hline
\end{tabular}

Tabel 8 Peraturan dan ekspektasi pada aktifitas pengeboran

\begin{tabular}{lll}
\hline Jenis aktifitas & Peraturan standar & Ekspektasi \\
\hline Pengiriman peralatan & 4 & 13 \\
\hline Penunjukan pekerja & 3 & 5 \\
\hline Peralatan penunjang dan aksesorisnya & 9 & 17 \\
\hline Persiapan akhir (inspeksi) & 8 & 22 \\
\hline Persiapan tempat & 8 & 14 \\
\hline Total & 19 & 55 \\
\hline
\end{tabular}




\section{Model pengendalian risiko dan peluang}

Klausul 4 ruang lingkup organisasi yang dirangkum pada dua model sebelumnya, diambil sumber data klausul 4.1 pengertian internal eksternal isu dan klausul 4.2 mengenai peraturan standar yang dikeluarkan oleh pihak berkepentingan terkait dengan isu pada klausul 4.1. Pada Gambar 10 pengendalian risiko berasal dari klausul 4 dan data penilaian risiko aktifitas. Lembar kerja query dapat dilihat pada Gambar 11

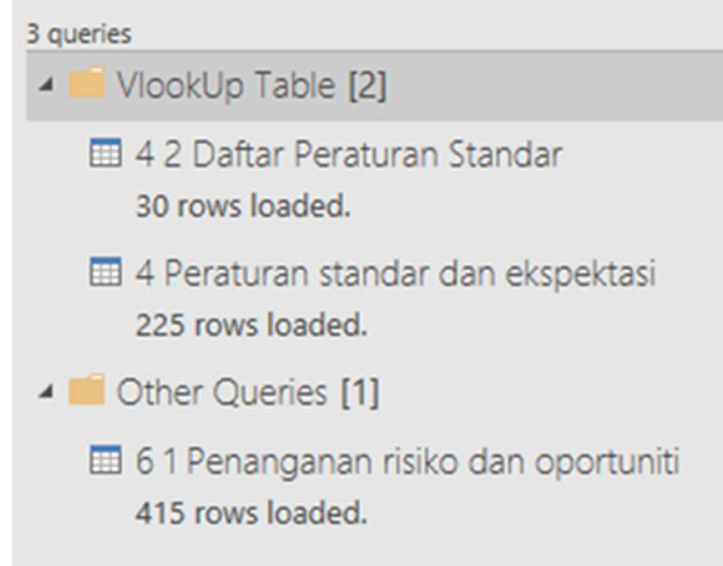

Gambar 11 Lembar kerja query pengendalian risiko dan peluang.

Apabila terdapat risiko baru yang ada dalam kegiatan atau aktifitas lakukan proses "refresh" secara berurutan untuk memastikan aktifitas telah memiliki saran pengendalian sesuai dengan peraturan standar. Hasil pemodelan pada kegiatan pengeboran terdapat 90 paparan risiko dan produksi sebanyak 325 , dapat dilihat pada tabel 9. Jenis aktifitas pemboran dan produksi dapat dilihat pada Tabel 10 dan 11.

Tabel 9 Paparan risiko pada kegiatan pemboran dan produksi

\begin{tabular}{cccc}
\hline Aktifitas utama & Jumlah peraturan & Paparan risiko & \% \\
\hline Pengeboran & 19 & 90 & 22 \\
\hline Produksi & 23 & 325 & 78 \\
\hline
\end{tabular}

Tabel 10 Paparan risiko aktifitas pengeboran

\begin{tabular}{ccccc}
\hline Jenis aktifitas utama & Peraturan & Ekpektasi & Paparan risiko & $\mathbf{\%}$ \\
\hline Pengiriman peralatan & 4 & 13 & 17 & 19 \\
\hline Penunjukan pekerja & 3 & 5 & 5 & 6 \\
\hline Peralatan penunjang dan aksesorisnya & 9 & 17 & 22 & 24 \\
\hline Persiapan akhir & 8 & 22 & 30 & 33 \\
\hline Persiapan tempat & 8 & 14 & 16 & 18 \\
\hline Total & 19 & 55 & 90 & 100 \\
\hline
\end{tabular}

Tabel 11 Paparan risiko aktifitas produksi.

\begin{tabular}{ccccc}
\hline Jenis Aktiffitas Utama & Peraturan & Ekpektasi & Paparan risiko & $\mathbf{\%}$ \\
\hline Penanganan hasil pemisahan & 11 & 21 & 82 & 25 \\
\hline Pengukuran laju produksi & 6 & 6 & 16 & 5 \\
\hline Peralatan pendukung & 21 & 59 & 174 & 54 \\
\hline Proses pemisahan aliran fluida sumur & 10 & 17 & 46 & 14 \\
\hline Testing sumur produksi & 5 & 5 & 7 & 2 \\
\hline Total & 23 & 72 & 325 & 100 \\
\hline
\end{tabular}


Basis data pengendalian risiko aktifitas digunakan sebagai alat verifikasi SMK3LL untuk kejadian dan penurunan kinerja, serta mempermudah perusahaan dalam memberikan saran perbaikan. Lingkup bahaya untuk kegiatan pemboran dan produksi dapat dilihat pada Gambar 12. Lingkup bahaya di bidang kesehatan industri, kimia dan ruang terbatas menempati urutan pertama dengan 9 jenis paparan risiko untuk kegiatan pemboran dan 73 pada aktifitas produksi. Pihak berkepentingan dapat dilihat pada Gambar 13 yang menunjukan Kementrian Tenaga Kerja dan Transmigrasi memiliki 293 paparan risiko yang telah dilengkapi saran perbaikan sesuai dengan aturan dan standar.

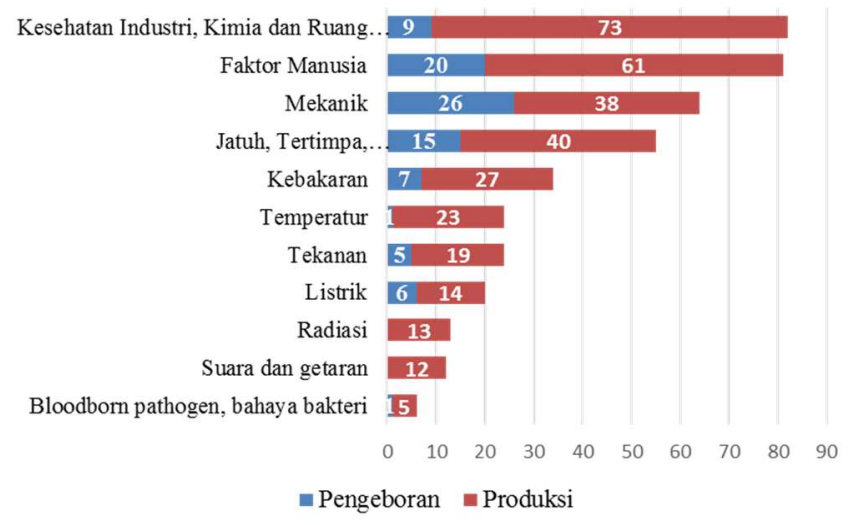

Gambar 12 Paparan risiko dan lingkup bahaya K3LL.

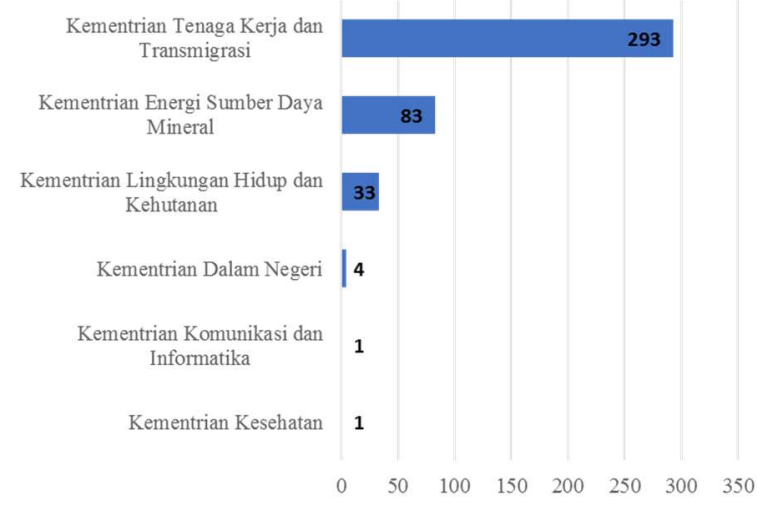

Gambar 13 Pihak berkepentingan dan apaparan risiko.

Lembar kerja basis data pengendalian risiko dan peluang dapat dilihat pada Gambar 14, yang menunjukan jumlah paparan risiko serta pengendalian berdasarkan peraturan dan standar yang berlaku.

\section{Model pelaporan kejadian K3LL dan perbaikan SMK3LL}

Menurut ISO 45001 (2018), ISO 14001 (2015) dan ISO 9001 (2015) klausul 10 menyatakan bahwa kejadian atau kecelakaan serta ketidaksesuaian dibidang K3LL memiliki fungsi untuk melakukan tindakan perbaikan setelah diketahui akar permasalahan. Proses perbaikan SMK3LL menggunakan data kejadian atau kecelakaan K3LL dan basis data pengendalian risiko, lingkup organisasi seperti basis data peraturan standar yang digunakan sebagai alat verifikasi. Variabel aktifitas atau kegiatan dan jenis bahaya menjadi faktor penentu model sistem pemberian saran perbaikan kinerja SMK3LL.

Lembar kerja pelaporan kejadian K3LL operasional lapangan terdiri dari tiga persamaan query, persamaan pertama berfungsi untuk memberikan laporan ke kantor pusat dan memperbarui basis data kejadian yang dimiliki oleh operasional lapangan dan kantor pusat Jakarta. Apabila saran belum diberikan oleh kantor pusat lembar kerja ini akan memberikan notifikasi atau pemberitahuan bahwa masih terdapat kejadian K3LL yang belum dievaluasi, setelah mendapat konfirmasi dari kantor pusat bahwa saran telah diberikan maka melakukan 
proses refresh pada persamaan query kedua dan ketiga untuk mendapatkan kesimpulan perbaikan. Lembar kerja query dapat dilihat pada Gambar 15.

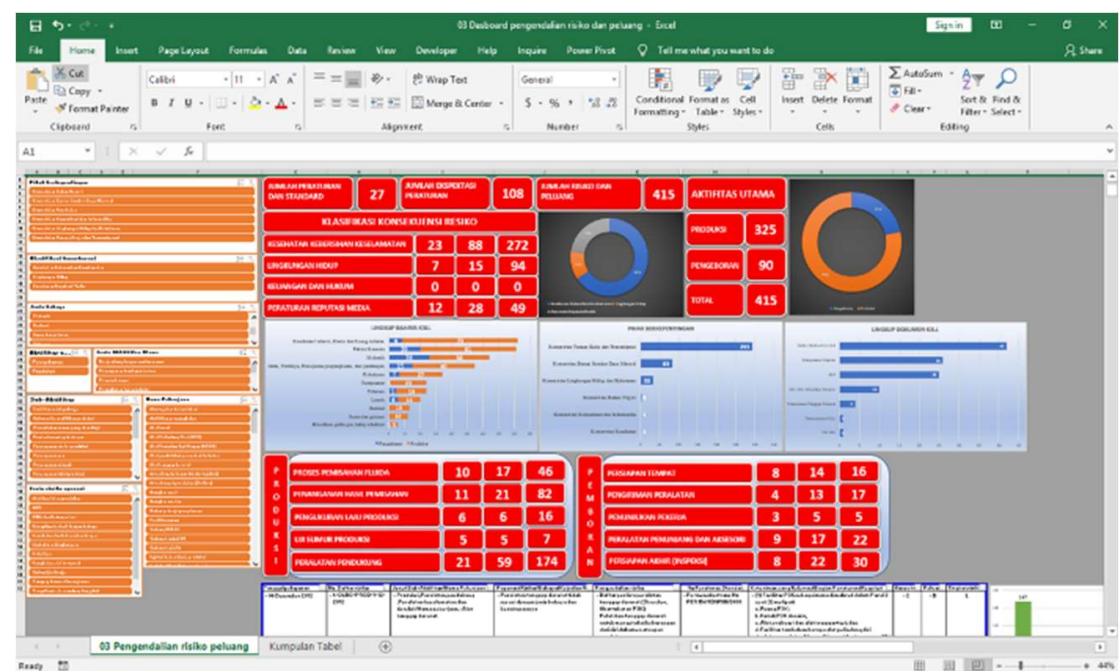

Gambar 14 Daftar penanganan risiko dan peluang.

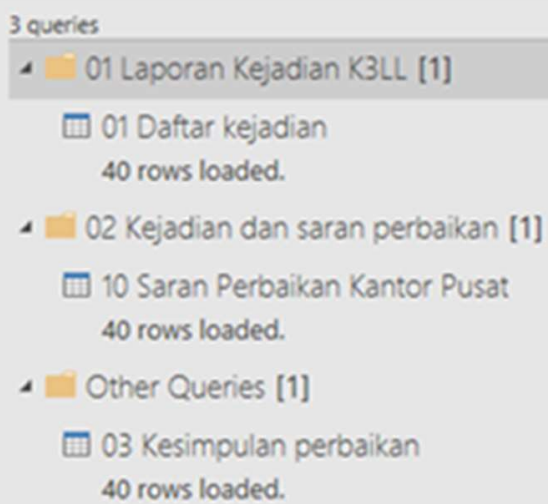

Gambar 15 Lembar kerja query pelaporan kejadian

Lembar kerja atau dashboard dapat dilihat dilihat pada Gambar 16. Slicer berguna untuk memfilter basis data kejadian dari tanggal, bulan, tahun, klasifikasi bahaya, klasifikasi kejadian PEP, dan aktifitas, dilengkapi dengan grafik dan tabel sebagai informasi awal sebelum melangkah pada tabel dinamis.

Diharapkan dengan pemodelan ini setiap terjadi penurunan kinerja K3LL seperti kejadian atau kecelakaan kerja, dapat segera diketahui rekomendasi pemecahan atau saran yang diberikan berdasarkan daftar analisa risiko, peraturan standar dan nilai risiko akhir apabila saran tersebut dilaksanakan dalam rangka perbaikan, nilai risiko menjadi rendah. Selama tahun 2013 sampai dengan Juni 2018, tercatat 41 kejadian dengan klasifikasi tambang atau non tambang dengan kriteria konsekuensi dan distribusi setiap tahun dapat dilihat pada Gambar 17 berdasarkan kejadian yang melibatkan kontraktor maupun perusahaan

Pada Gambar 17 menunjukan bahwa tahun 2015 terdapat 21 kejadian di bidang K3LL, frekwensi terbanyak dalam satu tahunnya. Pada tahun 2015 terdapat dua aktifitas yang berjalan secara bersamaan yaitu pengeboran sumur pengembangan dan aktifitas produksi. 


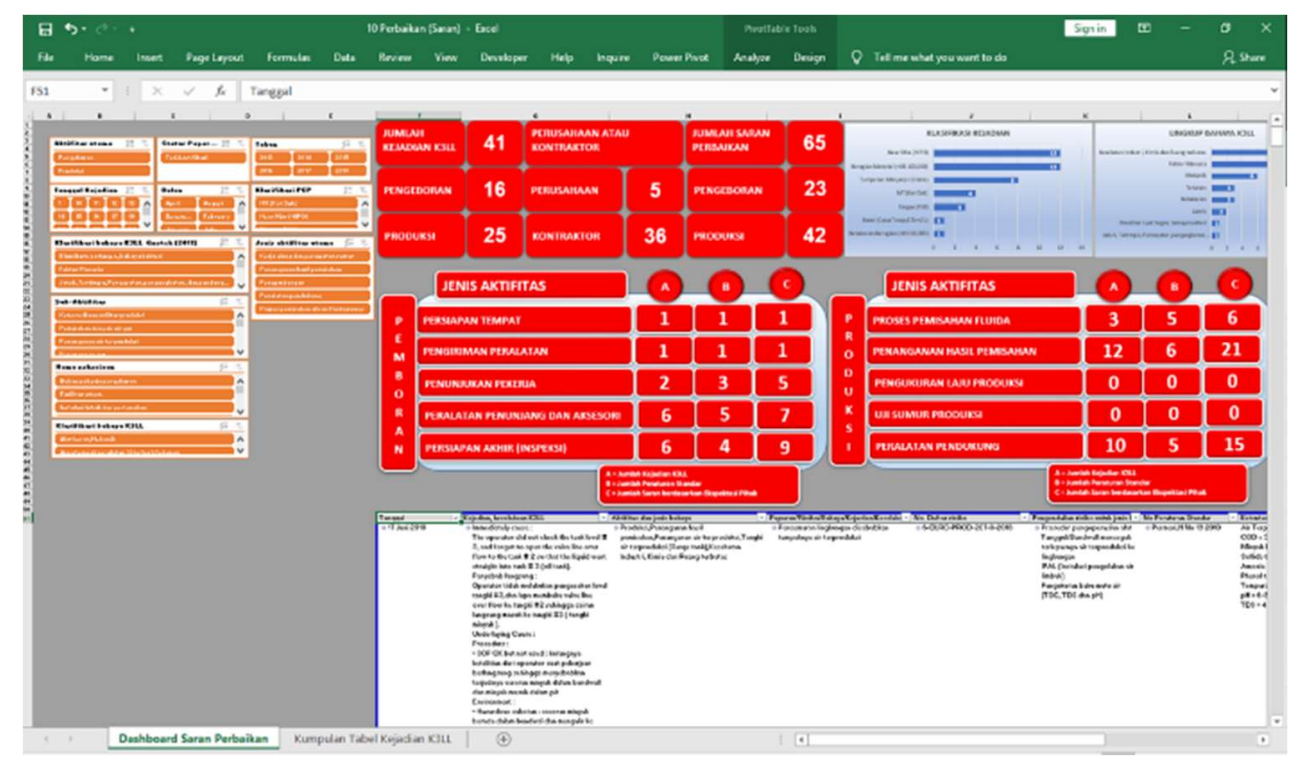

Gambar 16 Pelaporan kejadian K3LL (Lapangan).

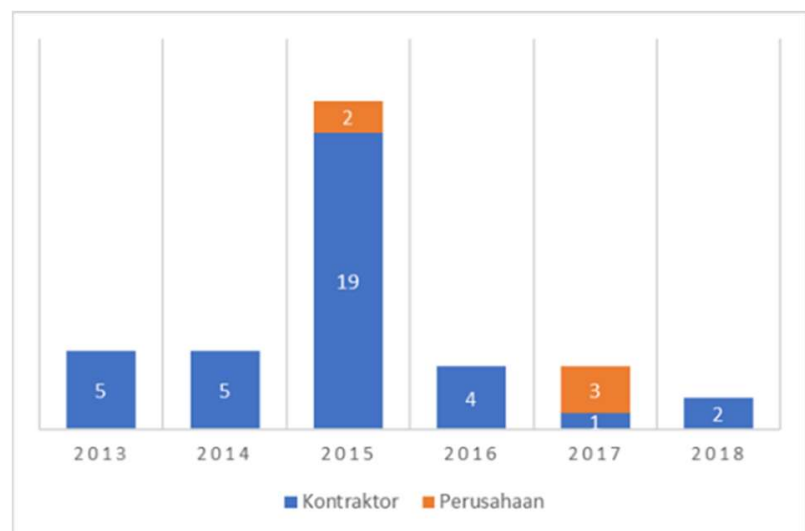

Gambar 17 Kejadian K3LL per tahun.

Tabel 12 Klasifikasi kejadian K3LL

\begin{tabular}{lll}
\hline Aktifitas & Klasifikasi PEP & $\begin{array}{c}\text { Kejadian, kecelakaan } \\
\text { K3LL }\end{array}$ \\
\hline Pengeboran & Near Miss (HIPO) & 9 \\
\hline & Kerugian Material $(<$ US 100,000) & 3 \\
\hline MT (Ket Dok) & 2 \\
\hline Tumpahan Minyak $(<10$ bbls) & 1 \\
\hline Produksi & Ringan (P3K) & 1 \\
\hline & Kerugian Material $(<$ US 100,000) & 9 \\
\hline & Tumpahan Minyak $(<10$ bbls $)$ & 7 \\
\hline & Near Miss (HIPO) & 3 \\
\hline & Ringan (P3K) & 2 \\
\hline & MT (Ket Dok) & 2 \\
\hline Kotal & Kebakaran Kerugian $(<$ US 10,000) & 1 \\
\hline & Berat (Cacat Tetap/LTI $>=21)$ & 1 \\
\hline
\end{tabular}


Klasifikasi kejadian menurut Pertamina EP dapat dilihat pada Tabel 28. Kejadian dengan klasifikasi hampir terjadi dengan nilai risiko tinggi terdapat 12 kejadian, disusul dengan tumpahan minyak kurang dari 10 bbls sebanyak 7 kejadian pada aktifitas produksi, 3 pada aktifitas pengeboran. Aktifitas pengeboran yang terdampak oleh kejadian K3LL, faktor manusia paling banyak menimbulkan kejadian atau penurunan kinerja. Aktifitas produksi jumlah kejadian dengan faktor bahaya K3LL, Kesehatan industri, kimia dan ruang terbatas seperti tumpahan minyak, iklim kerja merupakan jenis bahaya yang banyak mengakibatkan kejadian K3LL pada aktifitas produksi di kegiatan seperti penanganan hasil pemisahan, peralatan pendukung, serta proses pemisahan aliran sumur. Klasifikasi konsekuensi dapat dilihat pada Gambar 18.

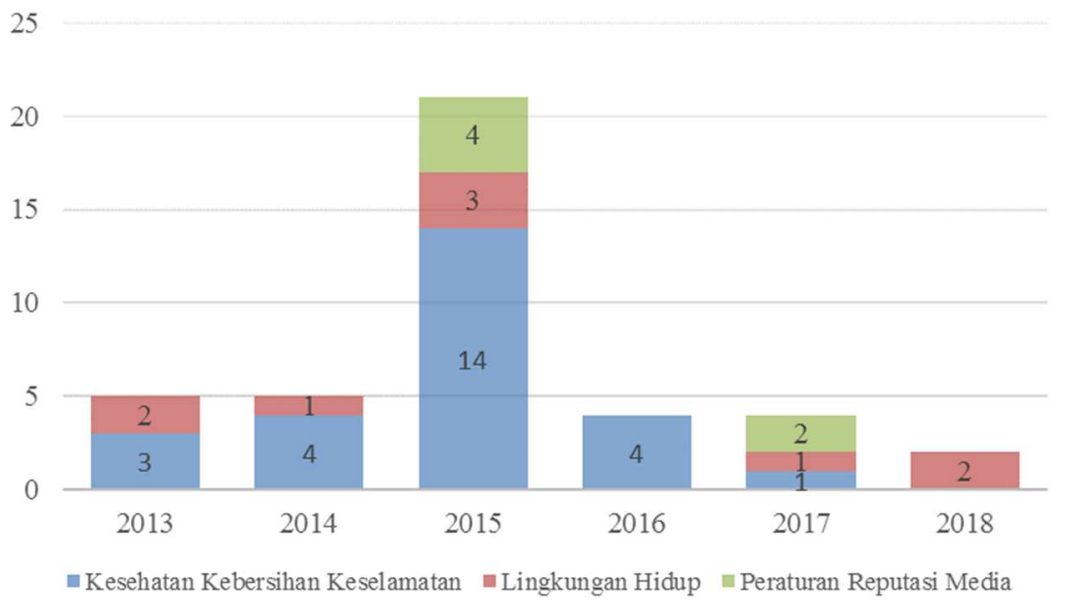

Gambar 18 Klasifikasi kosekuensi kejadian K3LL.

Pemodelan lembar kerja saran perbaikan menggunakan empat persamaan query. Persamaan pertama untuk mengupdate temuan K3LL, persamaan kedua adalah koneksi lembar kerja dengan basis data pengendalian risiko, persamaan ketiga untuk menotifikasi apabila kejadian masih belum terdaftar dalam basis data pengendalian risiko, persamaan keempat untuk memuat saran perbaikan. Perbaikan dari sistem yang dibangun dapat memberikan saran lebih dari satu untuk setiap kejadian tergantung pendataan bahaya dan risiko pada setiap aktifitas. Lembar kerja query dapat dilihat pada Gambar 19

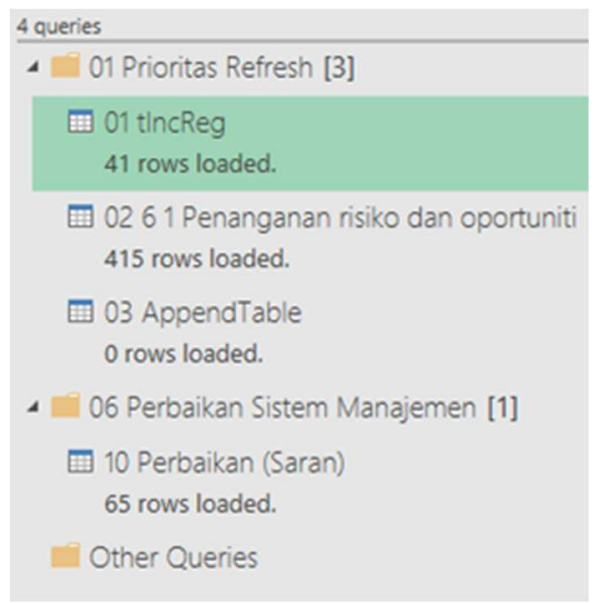

Gambar 19 Lembar kerja query saran perbaikan.

Total saran perbaikan yang dihasilkan dari pemodelan sistem untuk 41 kejadian di dua aktifitas utama, pengeboran dan produksi adalah 65 , dari total saran perbaikan pada basis data pengendalian risiko yang berjumlah 415. Tabel 13 dan 14 menunjukan jumlah peraturan dan saran yang dihasilkan dari pemodelan sistem pemantuan kinerja SMK3LL. 
Tabel 13 Jumlah saran perbaikan aktifitas pengeboran.

\begin{tabular}{lccl}
\hline Aktifitas & Kejadian K3LL & Peraturan Standar & Jumlah Saran \\
\hline Pengiriman peralatan & 1 & 1 & 1 \\
\hline Penunjukan pekerja & 2 & 3 & 5 \\
\hline Peralatan penunjang dan aksesorisnya & 6 & 5 & 7 \\
\hline Persiapan akhir (inspeksi) & 6 & 4 & 9 \\
\hline Persiapan tempat & 1 & 1 & 1 \\
\hline
\end{tabular}

Tabel 14 Jumlah saran perbaikan aktifitas produksi.

\begin{tabular}{llll}
\hline Aktifitas & Kejadian K3LL & Peraturan Standar & Jumlah Saran \\
\hline Penanganan hasil pemisahan & 12 & 6 & 21 \\
\hline Peralatan pendukung & 10 & 5 & 15 \\
\hline Proses pemisahan aliran fluida sumur & 3 & 5 & 6 \\
\hline
\end{tabular}

Model untuk rekomendasi saran perbaikan, ada beberapa hal yang harus dilakukan oleh kantor pusat dengan menggunakan lima persamaan query dapat dilihat pada Gambar 20. Persamaan pertama untuk menerima kejadian K3LL, kedua untuk status peraturan standar, persamaan ketiga dan kempat adalah untuk mengupdate basis data pengendalian risiko dan harapan dari pihak berkepentingan. Lembar kerja query dapat dilihat pada Gambar 21. Model tampilan muka interaksi antara operasional lapangan dan kantor pusat menggunakan batuan Microsoft Power Point sebagai media hyperlink ke masing masing lembar kerja.

Penurunan risiko dapat dilihat pada Gambar 22. Menunjukan semua kejadian telah diturunkan tingkat risiko sampai ketingkat rendah. Terdapat satu kejadian yang masih masuk risiko sedang. Kondisi ini disepakati bersama oleh manajemen perusahaan, sebagai acuan untuk memperketat pengawasan untuk pekerjaan yang sama, hal tersebut untuk kejadian dialami oleh perusahaan yang mengakibatkan hilangnya perhitungan hari kerja selamat.

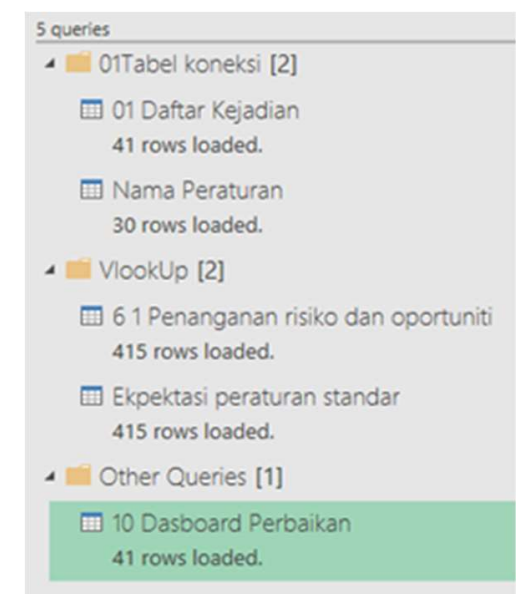

Gambar 20 Lembar kerja query rekomendasi saran perbaikan. 


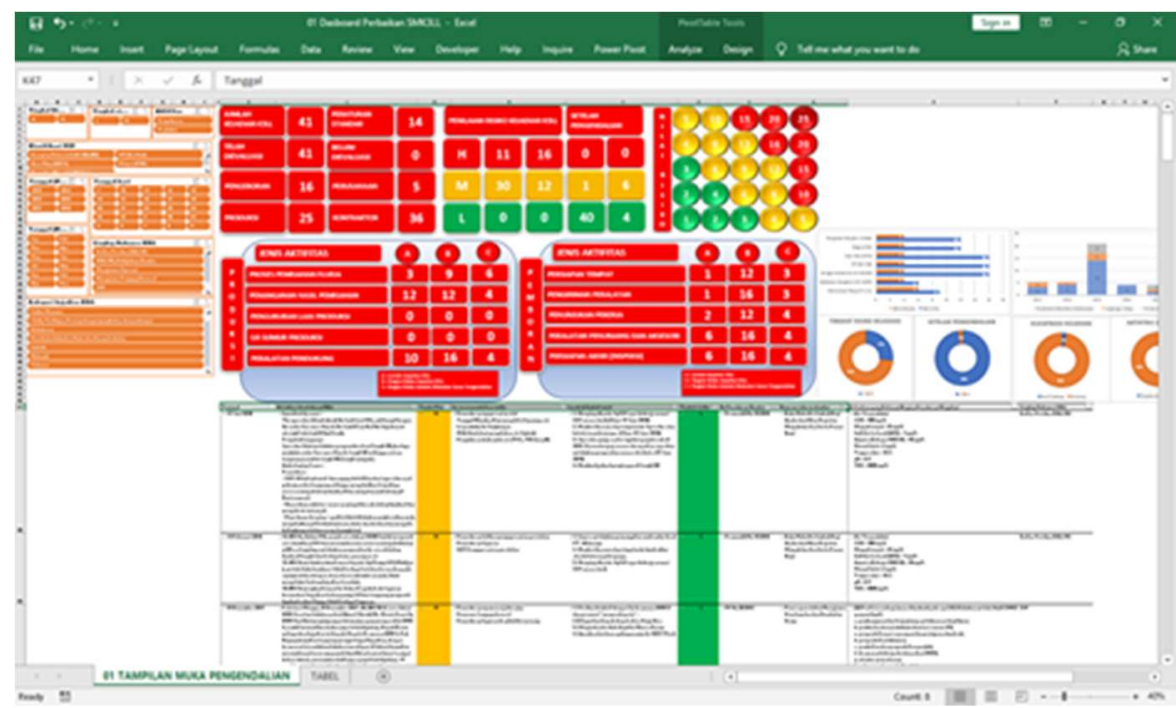

Gambar 21 Rekomendasi perbaikan (Kantor pusat).

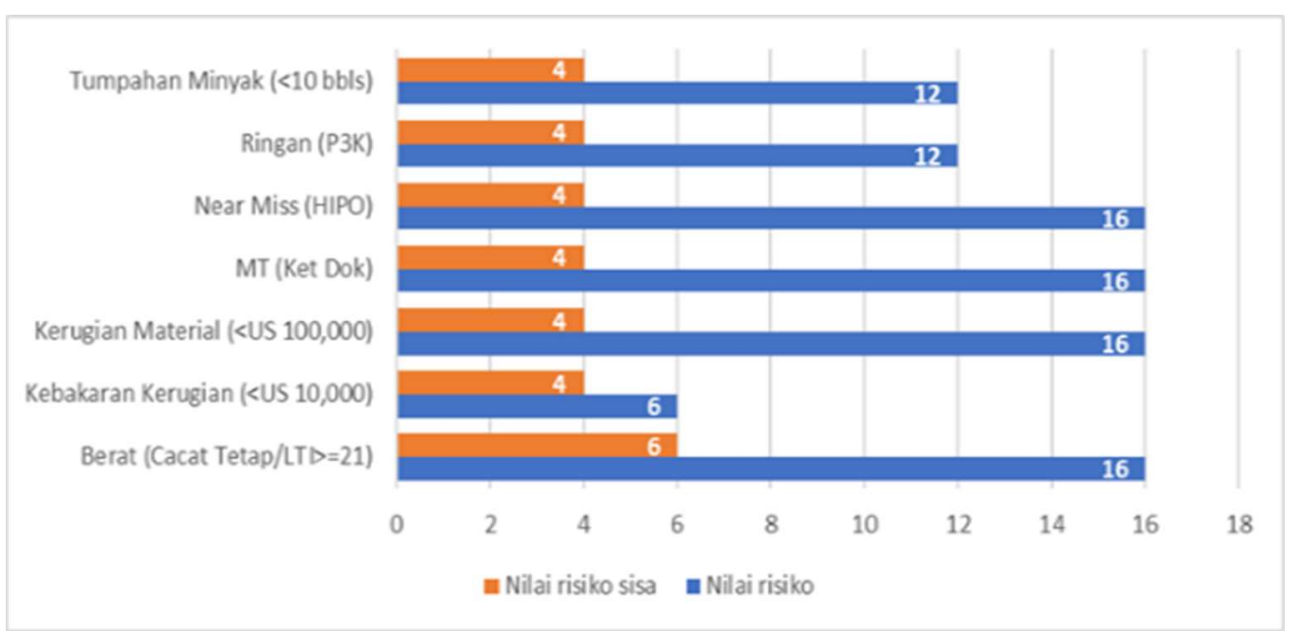

Gambar 22 Penilaian risiko setelah dilakukan pengendalian.

Aktifitas produksi faktor kesehatan industri, kimia dan ruang terbatas memiliki kontribusi terbesar terhadap kejadian atau penurunan kinerja K3LL, dengan aktifitas produksi penanganan hasil pemisahan, peralatan pendukung, proses pemisahan aliran fluida sumur. Terdapat 11 kejadian penurunan kinerja SMK3LL atau sekitar 44 persen. Risiko dari bahaya ini adalah tercemarnya lingkungan oleh sifat dari bahan yang dikelola dalam proses produksi, mulai dari penanganan air terproduksi, penanganan minyak, dan jalur pemipaan. Saran dari pemodelan adalah dengan meningkatkan prosedur kerja, pengecekan secara rutin baku mutu air drainase sesuai dengan peraturan, serta perbaikan fasilitas produksi sesuai dengan peraturan atau standar yang berlaku.

Kejadian pada aktifitas pengeboran dengan faktor manusia yang memiliki kontribusi terbesar pada setiap sub aktifitas seperti, penunjukan pekerja 2 kejadian, peralatan penunjang dan aksesori 3 kejadian, persiapan akhir 2 kejadian dan persiapan tempat 1 kejadian. Total faktor manusia memiliki kontribusi 50 persen dari total kejadian. Untuk kegiatan penunjukan pekerja terdapat dua kejadian terkait dengan pengamanan dan pergantian pekerja yang memasuki masa istirahat atau libur bekerja, saran yang diberikan dari sistem pemodelan sesuai dengan peraturan yang berlaku yaitu PP No 50 tahun 2012, mengenai penerapan sistem manajemen keselamatan kesehatan kerja, UU No 1 tahun 1970 tentang keselamtan kerja menyarankan meninjau ulang prosedur akses masuk, pembuatan pagar keliling lapangan serta melakukan pelatihan pada pengunjung ataupun pekerja yang baru masuk, penyebab tidak terpantaunya jadwal libur pekerja, sistem menyarankan untuk 
mengkaji ulang prosedur pergantian pekerja pemboran sesuai peraturan bahwa setiap pekerja mempunyai hak perlindungan atas kesehatan dan keselamatan kerja. Untuk peralatan penunjang dan aksesoris terdapat pada kegiatan transportasi pekerja, peralatan angkat dan pengelasan. Pada transportasi pekerja terjadi gangguan keamanan dari penduduk sekitar, peralatan angkat, tertabraknya tali pancang pemboran oleh boom alat angkat (Crane). Aktifitas pengelasan terjadi tertukarnya isi botol atau tabung pengelasan yang dapat mengeakibatkan kejadian fatal terkait sifat zat yang mudah meledak, saran yang diberikan oleh sistem adalah dengan meningkatkan pelaksanaan pengawasan prosedur kerja, komunikasi antar pekerja, memastikan kopetensi pekerja pada saat proses penunjukan pekerja, dapat dilihat pada Tabel 15.

Tabel 15 Kejadian K3LL dan penilaian risiko aktifitas pengeboran.

\begin{tabular}{cccc}
\hline Aktifitas & Kejadian K3LL & Nilai risiko (Maksimal) & Nilai risiko sisa (Maksimal) \\
\hline Pengiriman peralatan & 1 & 16 & 3 \\
\hline Penunjukan pekerja & 2 & 12 & 4 \\
\hline $\begin{array}{c}\text { Peralatan penunjang dan } \\
\text { aksesorisnya }\end{array}$ & 6 & 16 & 4 \\
\hline Persiapan akhir (inspeksi) & 6 & 16 & 4 \\
\hline Persiapan tempat & 1 & 12 & 3 \\
\hline
\end{tabular}

Berdasarkan klasifikasi kejadian K3LL dikeluarkan oleh Pertamina EP, kejadian dengan klasifikasi hampir terjadi dengan potensi kerugian tinggi pada aktifitas peralatan penunjang dan aksesori terdapat 4 kejadian dan persiapan akhir (Inspeksi) 5 kejadian, dengan faktor manusia sebanyak $56 \%$ diikuti oleh faktor mekanik 22\%, tekanan $11 \%$ dan Kesehatan industri kimia dan ruang terbatas $11 \%$. Saran perbaikan berdasarkan model pengendalian risiko untuk faktor manusia adalah pelatihan atau sosialisasi prosedur kerja terkait dengan operasional pengeboran, seperti prosedur tanggap darurat, isolasi sumber energi pada peralatan sebelum melakukan perbaikan, memastikan kopetensi operator angkat angkut serta prosedur pengamatan bahaya pekerjaan serta ijin kerja. Peraturan standar pada data base untuk jenis bahaya faktor manusia terdapat 4 yang mengatur pesawat tenaga produksi, pesawat angkat angkut, kwalitas juru las serta aturan penerapan sistem manajemen Keselamatan dan Kesehatan Kerja. Kejadian hampir terjadi disebabkan oleh faktor bahaya mekanik penurunan kinerja pada saat melakukan aktifitas persiapan akhir (inspeksi), terkait dengan peralatan angkat, saran yang diberikan adalah memperbaiki prosedur pemeriksaan peralatan angkat menara pemboran, dan memastikan adanya suku cadang pengganti, terdapat satu peraturan standar yang digunakan mengenai pesawat angkat angkut

Tabel 16 Kejadian K3LL dan penilaian risiko aktifitas produksi.

\begin{tabular}{cccc}
\hline Aktifitas & Kejadian K3LL & $\begin{array}{c}\text { Nilai risiko } \\
\text { (Maksimal) }\end{array}$ & $\begin{array}{c}\text { Nilai risiko sisa } \\
\text { (Maksimal) }\end{array}$ \\
\hline Penanganan hasil pemisahan & 12 & 12 & 4 \\
\hline Peralatan pendukung & 10 & 16 & 4 \\
\hline $\begin{array}{c}\text { Proses pemisahan aliran fluida } \\
\text { sumur }\end{array}$ & 3 & 9 & 6 \\
\hline
\end{tabular}

Kegiatan produksi dapat dilihat pada Tabel 16, aktifitas penanganan hasil pemisahan memiliki tingkat kejadaian tertinggi sebanyak 12 kejadian disusul aktifitas peralatan pendukung dan proses pemisahan fluida sumur. Faktor bahaya kesehatan industri kimia dan ruang terbatas ada 11 kejadian atau $44 \%$ serta faktor manusia 4 kejadian 16\%. Klasifikasi kejadian K3LL yang sering terjadi adalah kerugian material kurang dari 100.000 USD dan tumpahan minyak kurang dari 10 bbls. Kejadian dengan faktor bahaya kesehatan industri kimia dan ruang terbatas paling banyak adalah tumpahan minyak 7 kejadian, kerugian material diakibatkan 
kerusakan peralatan 2 kejadian dan peristiwa hampir terjadi 2 kejadian. Saran yang diberikan oleh model sistem adalah mensosialisasikan prosedur kerja peralatan, memantau setiap perubahan prosedur atau proses kerja dan dikomunikasikan, membuat daftar periksa untuk pelindung pasif tumpahan minyak seperti tanggul, perancangan sistem drainase dan perbaikan jadwal perawatan peralatan produksi. Peraturan standar terkait dengan faktor bahaya terdapat 3 yang mengatur alat pelindung diri, baku mutu air limbah dan keselamtan kerja pada pemurnian dan pengolahan minyak dan gas bumi. Faktor bahaya kedua adalah faktor manusia, klasifikasi kejadian adalah kerugian material yang disebabkan oleh gangguan keamanan, saran yang diberikan oleh sistem adalah peningkatan sistem pengamanan, mensosialisasikan dan mensimulasikan penanganan tanggap darurat, pengembangan saran dilakukan oleh KSO CESL dengan melakukan kerja sama dengan pihak berwajib dalam melakukan patroli pengamanan. Peraturan standar sebagai acuan adalah yang mengatur tentang penerapan sistem manajemen keselamatan kesehatan kerja.

Untuk penyusunan rencana kegiatan K3LL yang dilakuakan setiap tahunnya dapat menggunakan basis data klausul 6 perencanaan model pengendlian risiko dengan menitik beratkan pada kegiatan yang sering mengalami penurunan kinerja atau kejadian K3LL, contoh untuk pengelolaan air terproduksi yang memiliki kontribusi cukup besar dengan cara menyaring aktifitas penanganan air terproduksi sehingga di dapat daftar pengendalian risiko. Daftar ini selanjutnya dijadikan dasar untuk melakukan penilaian risiko, langkah perbaikan dan menentukan sumber daya yang dibutuhkan baik dari sisi sumber daya manusia maupun dana untuk perbaikan SMK3LL.

\section{KESIMPULAN}

Pemodelan sistem pemantauan kinerja K3LL dengan menggunakan data kejadian atau penurunan kinerja K3LL dapat membantu pekerja khususnya departemen K3LL dalam memberikan saran terhadap suatu peristiwa yang menurunkan kinerja K3LL dan dapat menyebabkan kerugian. Alat verifikasi sistem menggunakan data klausul 4 tentang lingkup organisasi dan klausul 6 pengendalian risiko dan oportuniti. Daftar pengendalian risiko untuk kegiatan pengeboran dan produksi berdasarkan data lembar analisa risko menghasilkan 415 jenis risiko kegiatan dengan klasifikasi konsekuensi kesehatan kebersihan keselamatan sebesar 272 risiko, lingkungan hidup 49 risiko dan peraturan reputasi media 94 risiko. Daftar pengendalian risiko dapat berkembang sesuai dengan kegiatan analisa risiko perencanaan yang dilakukan oleh KSO CESL serta temuan dari proses pelaksanaan kegiatan. Total Bahaya untuk aktifitas utama pengeboran sumur pengembangan sebanyak 90 risiko dan pengendaliannya. Produksi sebanyak 325 risiko berikut dengan pengendaliannya. Peraturan standar pihak berkepentingan untuk aktifitas pengeboran berjumlah 19, aktifitas produksi berjumlah 23 dari total 28 peraturan standar yang ada dalam lembar kerja.

Perbaikan SMK3LL menggunakan data kejadian dan kecelakaan mulai tahun 2013 sampai dengan bulan juni 2018. Aktifitas pengeboran terdapat 16 kejadian dengan jumlah peraturan standar 14 dan jumlah saran perbaikan 23, jumlah rekomendasi saran yang dipilih sebanyak 16. Aktifitas produksi terdapat 25 kejadian dengan jumlah peraturan standar 16 dengan jumlah saran perbaikan 42 dan jumlah rekomendasi saran perbaikan 25. Pada aktifitas pengeboran perbaikan SMK3LL berdasarkan kejadian K3LL adalah dengan mensosialisasikan prosedur kerja pengeboran khususnya untuk mengisolasi energi peralatan yang akan diperbaiki, kopetensi pekerja harus ditekankan pada aktifitas penunjukan pekerja, sehingga diharapkan kejadian yang diakibatkan oleh faktor manusia dapat berkurang. Pada aktifitas produksi untuk mengurangi kejadian tumpahan minyak yang dapat menimbulkan dampak lingkungan, melakukan perbaikan fasilitas serta pelatihan penanggulangan tanggap darurat dapat dilakukan untuk melakukan pengendalian kejadian yang disebabkan oleh faktor manusia dan peralatan produksi. 


\section{DAFTAR PUSTAKA}

[ISO] International Standar 45001. 2018. Occupational Health and Safety Management System. Ed ke-1. Geneva: BSI Standards Limited 2018.

[OGP] International Association of Oil and Gas Producers. 2013. Safety Data Reporting Users' Guide, 2013 Data. London: OGP.

[TIPKM] Tim Independen Pengendalian Keselamatan Migas. 2017. Atlas Keselamatan Migas Edisi Tahun 2017. Volume ke-2. Jakarta: Direktorat Jendral Minyak dan Gas Bumi.

Allington M, 2016. Learn to write DAX. Merritt Island: Holly Macro! Books.

Arnold K, Maurice S. 1999. Surface Production Operation. Ed ke-2. Woburn: Butterworth-Heinemann.

Budiarto G, Fredian Y, Nimmi Z. 2018. Strategi Sinkronisasi Implementasi Sistem Penjaminan Mutu Internal (SPMI) dengan ISO 9001 Program Sarjana IPB. Jurnal Aplikasi Manajemen dan Bisnis. 4(2). http://dx.doi.org/10.17358/jabm.4.2.202.

Goetsch DL. 2011. Occupational Safety and Health: Ed ke-7. New Jersey: Pearson Education, Inc.

Haight JM. 2016. Handbook of Loss Prevention Engineering. Weinheim: Wiley-VCH Verlag GmbH \& Co.

Hughes P, Ed F. 2009. Introduction to Health and Safety at Work: Ed ke-4. Burlington: Elsevier ButterworthHeinemann.

Karla MPC, Flavio P, Gladis C, Edna MQOC. 2015. Benefits in the Implementation of Safety, Health, Environmental and Quality Integrated System. IACSIT. 7(4): 333-338. doi: 10.7763/IJET.2015.V7.814.

Puls K, Miguel E. 2016. $M$ is for (Data) Monkey. Merritt Island: Holly Macro Books.

Purwanto AHD, Budi S, Ujang S, Heny KD. 2014. Implementing Health Safety Environment (HSE) Process Management to Improve HSE Performance, Competitive Advantage and Financial Performance. Jurnal Manajemen Teknologi. 13(1): 64-65. http://dx.doi.org/10.12695/jmt.2014.13.1.5.

Rubiandini R. 2012. Teknik Operasi Pemboran: Volume ke-1. Bandung: Penerbit ITB. 